\title{
ANALISIS POTENSI AIR SUNGAI PADA EMBUNG 190 DI PG. BUNGAMAYANG PTPN VII, LAMPUNG
}

\author{
(The Analysis of River Water Potential on $190^{\text {th }}$ Small Dam in Pg. Bungamyang PTPN \\ VII, Lampung)
}

\author{
Melvin Classy Alexander Tarigan ${ }^{1}$, dan Asep Sapei ${ }^{1 *}$ \\ ${ }^{1}$ Departemen Teknik Sipil dan Lingkungan IPB, Kampus IPB Dramaga, Bogor 16880 \\ *Penulis korespondensi: asepsapei@yahoo.com
}

Diterima: 12 Maret 2017

Disetujui: 12 April 2017

\begin{abstract}
Water is a very important element for sustainability of daily needs. Water also used as field irrigation. This research was serves to analyze the potential of river water in PG. Bungamayang PTPN VII, Lampung. This research conducted at 190th small dam in Sugar Factory of Bungamayang which is part of Tulang Bawang watershed and geographically located at $104^{\circ} 52^{\prime}$ 07" SL and 04 35' 24" EL. In this research, the SWAT analyze performed using ArcSWAT 2012 as a plug-in for ArcGIS 10. In these simulations, performed of 4 process, including the process of watershed delineation, establishment of hydrological response units (HRU), data processing and SWAT simulation, and visualization process. For validation process, observation discharge and simulation discharge of SWAT used for comparison from March $20^{\text {th }}$ until April $5^{\text {th }} 2014$. Based on SWAT simulation shown $0.066 \mathrm{~m}^{3} / \mathrm{s}$ average discharge and for observation discharge, shown 0.043 $\mathrm{m}^{3} / \mathrm{s}$ average discharge with 0.897 coeffesien correlation. The potential water shown by the annual average discharge which has been simulated by SWAT. The maximum average annual discharge is $0.143 \mathrm{~m}^{3} / \mathrm{s}$ on April and minimum average annual discharge is $0.018 \mathrm{~m}^{3} / \mathrm{s}$ on September. With the result of potential water river on $190^{\text {th }}$ small dam in PG Bungamayang PTPN VII, Lampung is 2 $373950.55 \mathrm{~m}^{3}$ every years.
\end{abstract}

Keywords: Tulang Bawang watershed, HRU, potential water, SWAT.

\section{PENDAHULUAN}

Air merupakan elemen yang sangat penting bagi keberlangsungan kehidupan makhluk hidup. Sungai yang digunakan untuk mengairi lahan pertanian maupun perkebunan harus memiliki ketersediaan air yang memadai sehingga mampu membuat lahan pertanian maupun perkebunan terjaga kebutuhan airnya (Zhang, 2004). Gambaran umum mengenai potensi air suatu daerah tercermin dari daerah aliran sungai (DAS). DAS merupakan suatu kawasan tata air, dibatasi oleh pemisah topografi (pegunungan atau perbukitan) berfungsi menampung, menyimpan dan mengalirkan curah hujan yang jatuh di kawasan tersebut ke sungai utama dan bermuara di laut atau danau. Informasi mengenai potensi ketersediaan air ini diperlukan pengembangan sektor pertanian di suatu kawasan.

Salah satu pengembangan sistem kelola air yang dilakukan di PG Bungamayang PTPN VII, Lampung adalah pembangunan embung. Embung berfungsi sebagai penampung air hujan maupun air sungai sehingga mampu dimanfaatkan saat musim kering. Embung 190 merupakan embung yang memanfaatkan aliran DAS Tulang Bawang yang mengaliri PG. Bungamayang sebagai cadangan air. Tujuan dari penelitian ini adalah menganalisis potensi air sungai pada embung 190 di PG. 
Bungamayang PTPN VII, Lampung menggunakan permodelan SWAT serta memperoleh debit rataan maksimum dan minimum tahunan

\section{METODE PENELITIAN}

\section{Waktu dan Lokasi Penelitian}

Penelitian ini dilaksanakan selama \pm 2 bulan yang akan dimulai dari bulan Maret April 2014. Penelitian dilakukan di PG. Bungamayang PTPN VII, Lampung.

\section{Alat dan Bahan}

Alat yang digunakan dalam penelitian ini antara lain pelampung, pita ukur, stopwatch, laptop yang telah dilengkapi dengan Microsoft Office 2013, ArcGIS, ArcSWAT 2012 dan SWAT Plot and Graph. Bahanbahan yang digunakan adalah Peta Digital Elevation Model (DEM) dengan resolusi 30 meter, peta tanah eksplorasi dari Badan Penelitian Tanah, Peta Citra Landsat TM sebagai peta penggunaan lahan, Data Klimatologi tahun 2002 - Mei 2014 (Curah Hujan dan Suhu harian) yang diperoleh dari Badan Penelitian dan Pengembangan PG. Bungamayang PTPN VII, Lampung, serta data pengukuran debit sungai pada Embung 190.

\section{Tahapan Penelitian}

Tahapan penelitian secara keseluruhan ini dapat digambarkan sesuai dengan diagram alir pada Gambar 1.

Dalam tahapan analisis SWAT, terdapat beberapa kegiatan yang akan dilakukan yaitu:

1. Delineasi Daerah Observasi

Proses delineasi menggunakan data DEM SRTM yang diolah menggunakan perangkat lunak ARCGIS 10.1. Daerah observasi ini akan didelineasi berdasarkan batas topografi alami DAS.

2. Pembentukan HRU (Hydrological Response Unit)

HRU adalah unit satuan lahan dengan unsur karakteristik sub DAS yang berpengaruh terhadap terjadinya erosi. Setiap HRU akan memiliki informasi sub DAS, nomor HRU, jenis penutupan lahan, jenis tanahm dan luas HRU. HRU didapatkan dari overlay peta tanah dan peta penggunaan lahan.

3. Penggabungan HRU dengan data iklim Proses penggabungan HRU dan data iklim dilakukan setelah saruan analisis terbentuk. Pada tahap ini ditentukan periode simulasi terlebih dahulu untuk kemudian dilakukan pemasukan data iklim.

4. Simulasi

Proses simulasi dilakukan setelah proses penggabungan HRU dengan data iklim. Persamaan yang digunakan di dalam simulasi SWAT untuk melakukan prediksi aliran permukaan adalah metode SCS Curve Number pada persamaan (2) dan (3).

5. Validasi

Dalam proses validasi ini, dilakukan plot hasil debit simulasi yang dihasilkan oleh SWAT dan debit observasi hasil pengamatan selama penelitian dilakukan. Untuk melihat kevalidan data sehingga dapat dilihat apakah data tersebut layak (valid) maupun tidak untuk dilanjutkan ke proses selanjutnya.

6. Simulasi dengan SWAT.

Setelah model SWAT sesuai dengan data aktual DAS, dilakukan analisis potensi debit air sungai rataan tahunan. Analisis yang dilakukan adalah dengan melakukan perbandingan antara debit hasil prediksi model SWAT terkalibrasi dengan kebutuhan air di PG. Bungamayang PTPN VII, Lampung. 


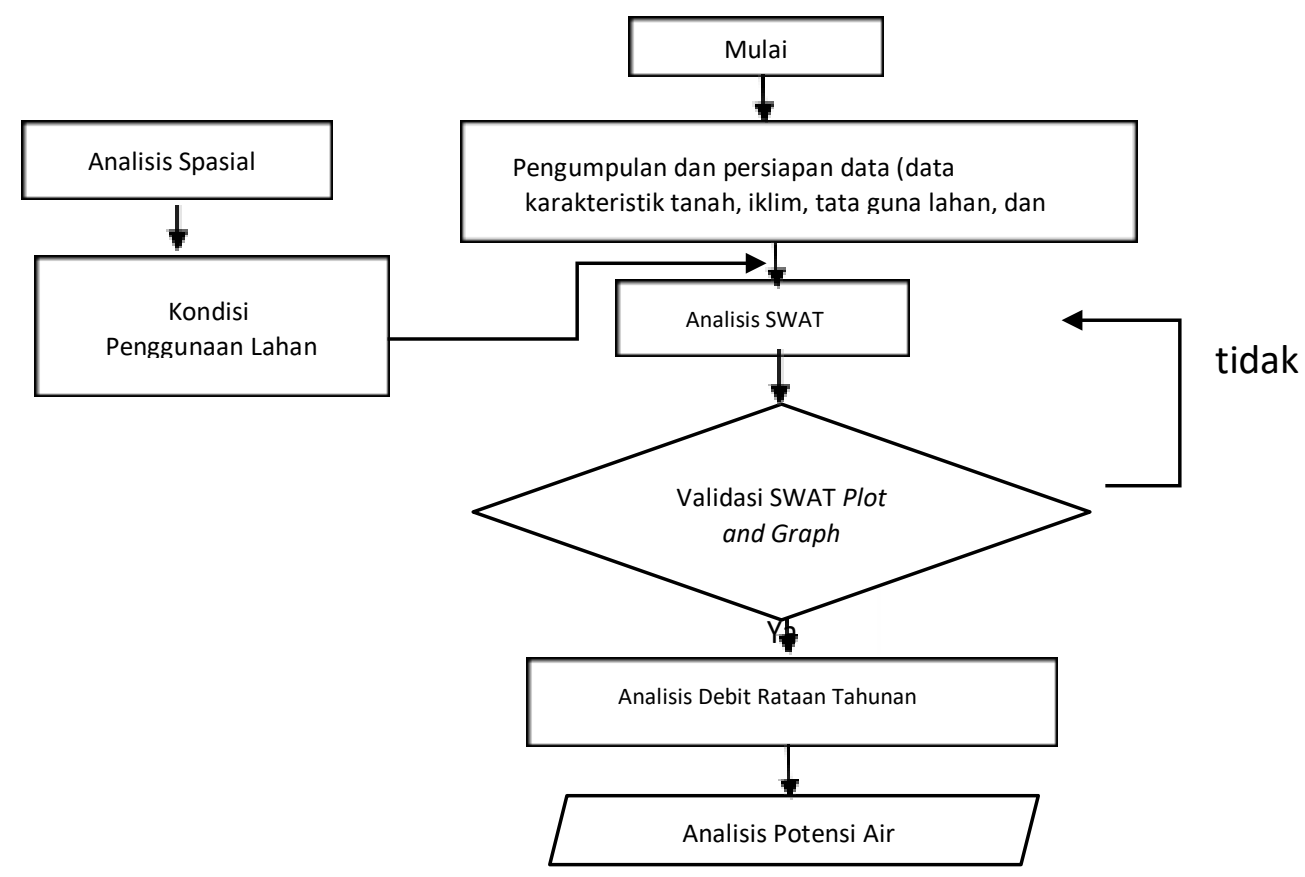

Gambar 1 Diagram Alir Penelitian

\section{HASIL DAN PEMBAHASAN}

\section{Keadaan Umum Lokasi Penelitian}

Lokasi Penelitian yang secara geografis terletak pada $04^{\circ} 35^{\prime} 24^{\prime \prime}$ LS dan $104^{\circ} 52^{\prime}$ 07' BT yang merupakan anak sungai dari Daerah Aliran Sungai (DAS) Tulang Bawang termasuk dalam zona 48 UTM. Lokasi penelitian memiliki luas sebesar $12.73 \mathrm{~km}^{2}$ atau $0.99 \%$ dari DAS Tulang Bawang yang memiliki daerah tangkapan seluas $1285 \mathrm{~km}^{2}$. Lokasi penelitian yang berada pada daerah Negara Ratu, Bungamayang yang berjarak $\pm 45 \mathrm{~km}$ dari Kotabumi sebagai ibukota kabupaten Lampung Utara dan \pm 157 dari Bandarlampung sebagai ibukota Propinsi Lampung.

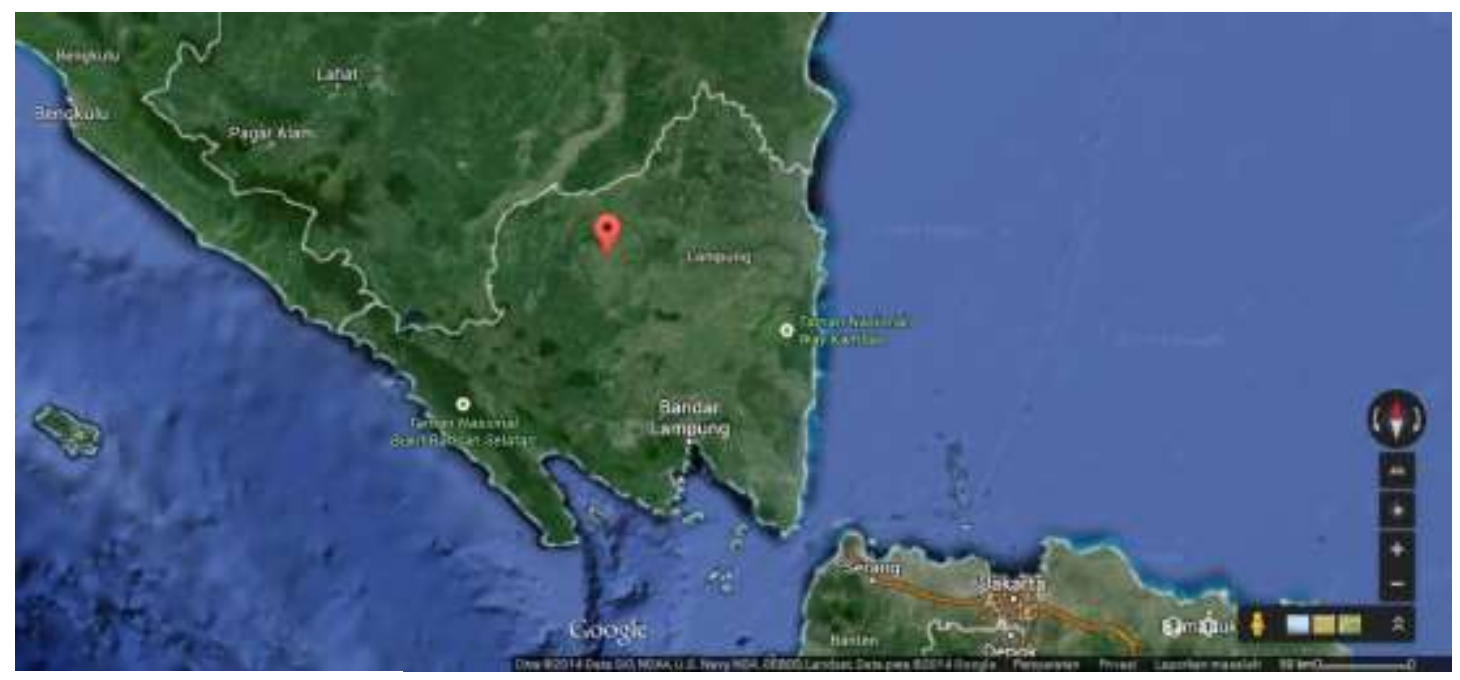


Pada penelitian ini, lokasi embung 190 yang terletak pada rayon I, PG. Bungamayang PTPN VII, Lampung digunakan sebagai outlet yang berlokasi pada $04^{\circ} 34^{\prime} 28^{\prime}$ ' LS dan $104^{\circ}$ 51' 51' BT. Penempatan dilakukan karena debit sungai yang diukur dapat dibandingkan dengan informasi total potensi air sungai yang mengalir di PG. Bungamayang PTPN VII, Lampung.

\section{Penggunaan Lahan}

Berdasarkan peta jenis tanah eksplorasi DAS Tulang Bawang, menunjukkan bahwa Bungamayang didominasi oleh Grumusol dengan luasan
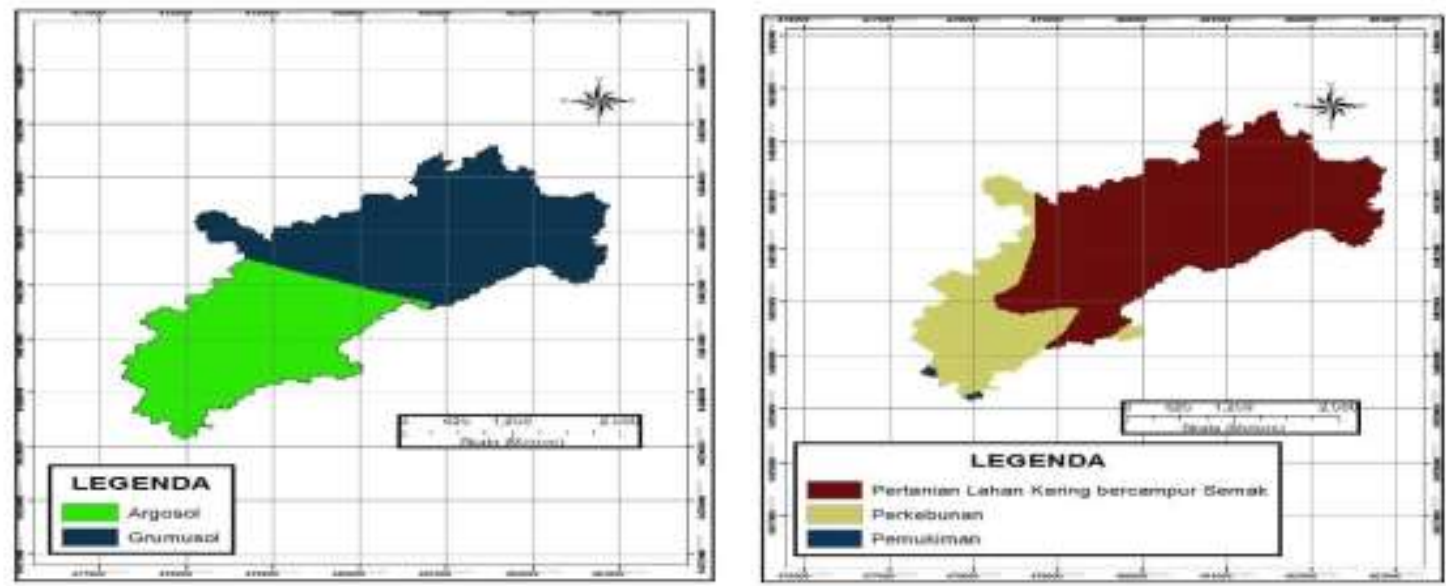

Gambar 3 Peta Tanah (kiri) dan Peta Penggunaan Lahan (kanan) daerah aliran sungai Embung 190

\section{Analisis SWAT}

\section{Proses Delineasi DAS}

Pada tahap pertama dilakukan, dilakukan delineasi daerah aliran sungai berdasarkan data digital elevation model (DEM) wilayah DAS yang akan diteliti. Data DEM yang digunakan pada penelitian ini adalah data ASTER Global DEM V2 dengan resolusi 30 meter. Pada tahap ini, data DEM dimasukkan terlebih dahulu, kemudian batas DAS ditentukan sehingga dapat diperoleh aliran sungai serta sub DAS. Ketepatan pembentukan aliran sungai dan sub DAS ditentukan oleh ketelitian dalam melakukan delineasi. Semakin kecil nilai kolom cells yang digunakan, maka semakin banyak
$7.08 \mathrm{~km}^{2}(55.6 \%)$ dan Argosol dengan luasan $5.65 \mathrm{~km}^{2}(44.4 \%)$.

Pada penelitian ini digunakan citra landsat 7 ETM+ dari Dinas Kementrian Kehutanan pada tahun 2011 sebagai informasi penggunaan lahan. Pada tahap pertama, data citra diolah menggunakan ArcGIS, kemudian diproyeksikan dengan WGS 1984 pada zona $48 \mathrm{~S}$, kemudian dilakukan pemotongan wilayah Embung terhadap citra. Berdasarkan citra landsat tersebut, Bungamayang didominasi oleh Pertanian Lahan Kering bercampur semak seluas 9.45 $\mathrm{km}^{2}(74.26 \%)$, kemudian perkebunan tebu seluas $3.22 \mathrm{~km}^{2}(25.28 \%)$ dan pemukiman seluas $0.06 \mathrm{~km}^{2}(0.46 \%)$. aliran sungai serta sub DAS yang terbentuk. Pada Gambar 6, digunakan ketelitian sebesear 50 ha, sehingga terbentuk DAS dengan total luasan 1273 ha.

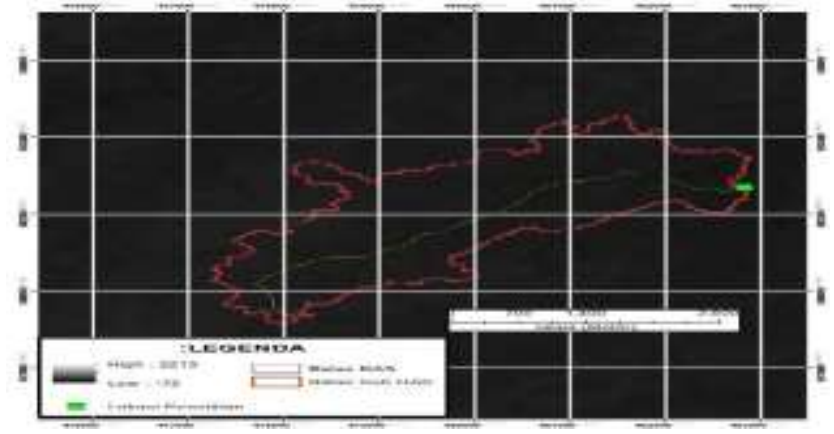

Gambar 4 Peta hasil delineasi daerah aliran sungai Embung 190

2. Pembentukan HRU

Setelah dilakukan proses delineasi, dilakukan pembentukan HRU (hidrologycal response unit). Pada tahap ini dilakukan 
overlay antara hasil data DEM, data penggunaan lahan, serta data tanah. Selain dapat melakukan analisis hidrologi berdasarkan karakteristik tanah dan penggunaan lahan yang spesifik, proses ini berguna dalam pemasukan data slope (kemiringan). Pada Gambar 5, dilakukan pengelompokan kemiringan sebesar 0-5\% (datar), 5-15\% (bergelombang), 15-30\% (agak curam) dan 30-45\% ( curam).

Hasil pembentukan HRU memberikan informasi mengenai penggunaan lahan, tanah, kemiringan lahan, luas area, dan presentase luas HRU pada sub DAS. Pada Gambar 5, diperoleh 18 HRU, di mana titik Embung 190 PG. Bungamayang berada di bagian hilir.

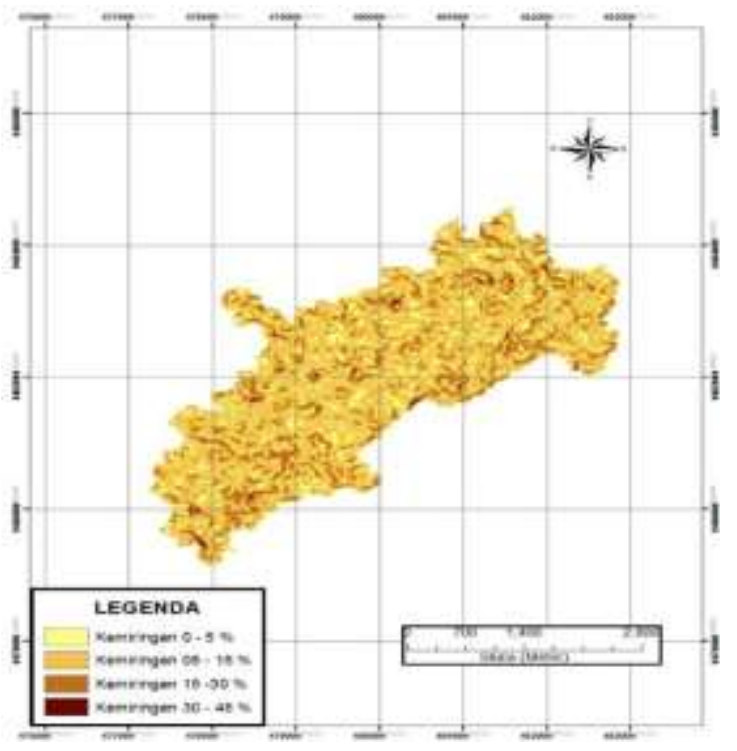

Gambar 5 Peta sebaran kemiringan (kiri) dan Peta HRU (kanan) daerah aliran sungai Embung 190
3. Proses Visualisasi

Pada tahap ini dilakukan proses visualisasi debit. Data debit yang divisualisasikan merupakan data debit harian serta debit bulanan. Hasil dari simulasi ditampilkan dengan menggunakan SWAT Plot and Graph. SWAT Plot and Graph juga dapat digunakan sebagai acuan validasi data. Pada Gambar 6, debit simulasi harian maksimum yang terjadi pada tanggal 20 Maret hingga 5 April 2014 adalah sebesar $0.463 \mathrm{~m}^{3} /$ detik dengan debit minimum sebesar $0.024 \mathrm{~m}^{3} /$ detik, serta debit rata-rata sebesar $0.066 \mathrm{~m}^{3} /$ detik. Sedangkan untuk debit observasi, debit maksimum yang diperoleh sebesar $0.116 \mathrm{~m}^{3} /$ detik, debit minimum sebesar $0.024 \mathrm{~m}^{3} /$ detik, serta debit rata-rata sebesar $0.043 \mathrm{~m}^{3} /$ detik. Dengan menggunakan SWAT Plot and Graph diperoleh koefesien korelasi sebesar 0.897.

Pada Gambar 7, menunjukkan fluktuasi potensi debit rataan tahunan Embung 190 PG. Bungamyang, PTPN VII, Lampung dari tahun 2002-2013 yang telah disimulasi oleh model SWAT. Berdasarkan grafik tersebut, diperoleh debit rataan maksimum tahunan sebesar $0.143 \mathrm{~m}^{3} /$ detik yang terjadi pada bulan April, debit rataan minimum tahunan sebesar $0.018 \mathrm{~m}^{3} /$ detik yang terjadi pada bulan September. 


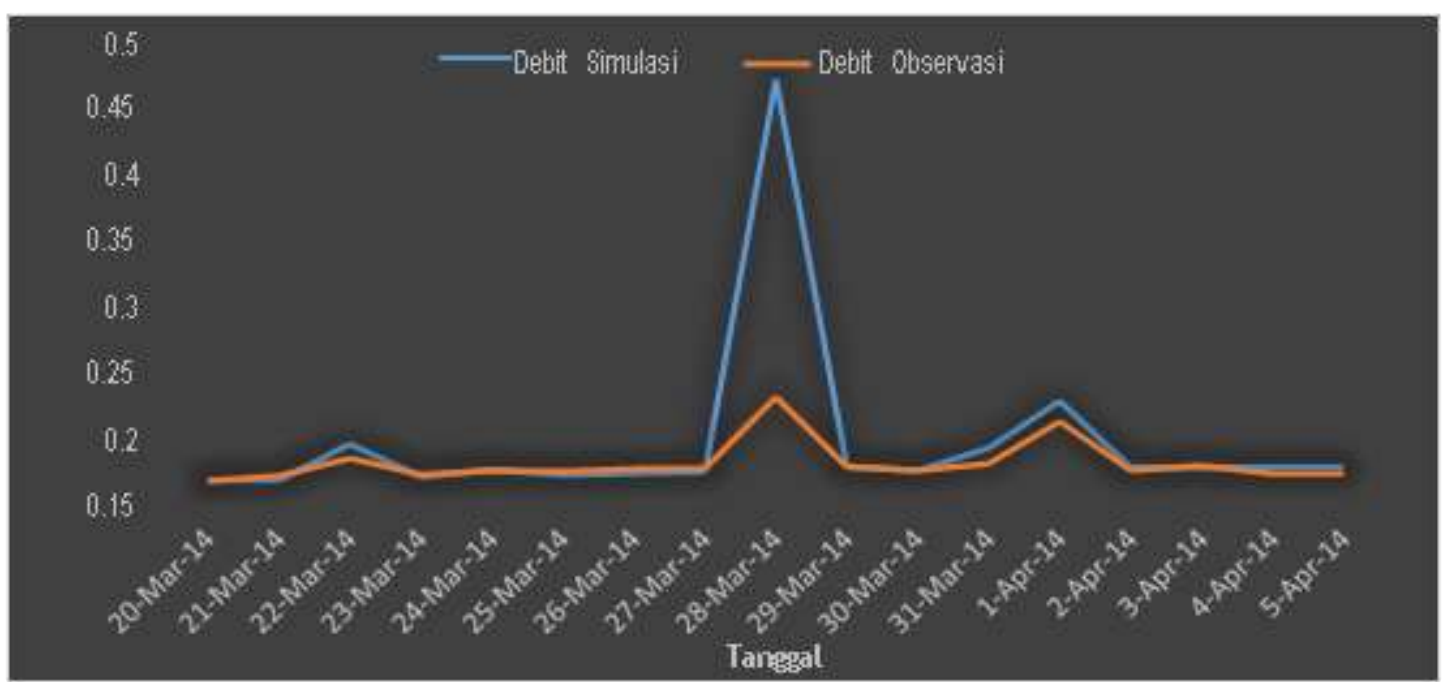

Gambar 6 Fluktuasi debit simulasi SWAT dan debit

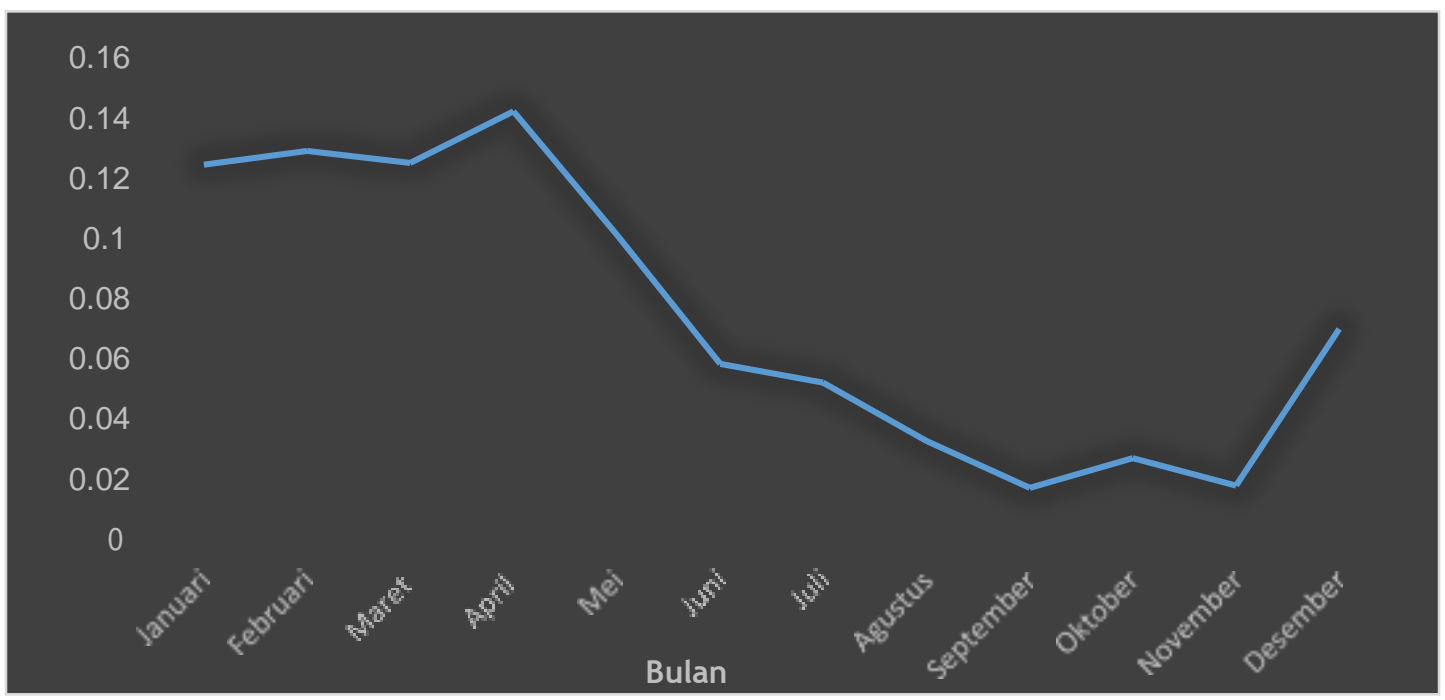

Gambar 7 Fluktuas debit rataan tahunan Bungamayang (2002 -20132013)

\section{Analisis Debit Sungai}

Setelah melalui tahap validasi model SWAT yang diperoleh dengan cara memplotkan hasil simulasi SWAT, dilakukan analisis terhadap simulasi SWAT dari tahun 2002 hingga 2013 guna memperoleh potensi debit rataan tahunan Embung PG. Bungamayang PTPN VII, Lampung. Namun demikian, analisis rataan tahunan model SWAT tidak dapat dilakukan kalibrasi dikarenakan tidak tersedianya data debit pengukuran yang mencukupi dalam jangka waktu tertentu sehingga hanya dilakukan proses validasi menggunakan debit hasil simulasi dan debit hasil observasi dari tanggal 20 Maret hingga 05 Juli 2014. Berdasarkan hal itu, permodelan SWAT dalam penelitian ini menggunakan parameter default tanpa kalibrasi.

Berdasarkan model SWAT untuk validasi, diperoleh debit simulasi harian maksimum yang terjadi pada tanggal 20 Maret hingga 5 April 2014 adalah sebesar $0.463 \mathrm{~m}^{3} /$ detik dengan debit minimum sebesar $0.024 \mathrm{~m}^{3} /$ detik, serta debit rata-rata sebesar $0.066 \mathrm{~m}^{3} /$ detik. Sedangkan untuk debit observasi, debit maksimum yang diperoleh adalah sebesar $0.116 \mathrm{~m}^{3} /$ detik yang terjadi pada tanggal 28 Maret 2014, debit minimum sebesar $0.024 \mathrm{~m}^{3} /$ detik yang terjadi pada tanggal 20 Maret 2014, serta debit rata-rata sebesar $0.043 \mathrm{~m}^{3} /$ detik.

Dalam penelitian ini terdapat beberapa error yang terjadi antara debit observasi dengan dengan debit simulasi SWAT. Hal 
ini dapat terjadi akibat adanya kesalahan dalam pengulangan pengukuran debit dimana pengukuran debit yang dilakukan menggunakan peralatan sederhana (pelampung dan stopwatch).

Untuk potensi debit rataan tahunan Embung 190 PG Bungamayang PTPN VII, Lampung dimana debit rataan maksimum tahunan diperoleh pada bulan April sebesar $0.143 \mathrm{~m}^{3} /$ detik dan potensi debit rataan minimum tahunan sebesar $0.018 \mathrm{~m}^{3} /$ detik yang terjadi pada bulan September. Dengan menggunakan debit rataan tahunan dari tahun 2002-2013, dapat diperoleh total volume potensi air sungai yang masuk ke Embung 190 PG Bungamayang PTPN VII sebesar $2373950.55 \mathrm{~m}^{3}$ tiap tahunnya. Volume debit ini yang masuk ke Embung 190 PG Bungamayang untuk digunakan sebagai pemenuhan kebutuhan irigasi perkebunan tebu.

\section{KESIMPULAN}

1. Dengan melakukan analisis potensi debit rataan tahunan, diperoleh debit rataan maksimum tahunan sebesar $0.143 \mathrm{~m}^{3} /$ detik yang terjadi pada bulan April dan rataan minimum tahunan sebesar $0.018 \mathrm{~m}^{3} /$ detik yang terjadi pada bulan September.

2. Berdasarkan debit rataan tahunan, diperoleh volume total potensi air sungai di Embung 190 PG. Bungamayang PTPN VII, Lampung sebesar $2373950.55 \mathrm{~m}^{3}$ tiap tahunnya.

\section{DAFTAR PUSTAKA}

Ahl RS, Scott W. Woods dan Hans R. Zuurig. 2008. Hidrological Calibration and Validation of SWAT in A SnowDominated Rocky Mountain Watershed, Montana. USA. Journal of The American Water Resources Association.

Anggana. 2013. Analisa Kebutuhan Air Irigasi pada Tanaman di Daerah Irigasi Poncowati dengan Menggunakan Software Cropwate 8. Jurusan Teknik Pengairan. Fakultas Teknik. Universitas Brawijaya Press

Arnold, J.G., J.R. Kiniry, dan J.R. Williems. 2005. Soil and Water Assessment Tool
Theoretical documentation (version 2005). Agriculture Research Sevice US. Retrieved October 31, 2008. http://swat.tamu.edu/media/1292/swat200 5theory

Asdak C. 1995. Hidrologi dan Pengolahan Daerah Aliran Sungai. Yogyakarta: Gadjah Mada University Press

Buku Standar Perencanaan Irigasi (Kriteria Perencanaan Bagian Bangunan Utama KP-02), CV Galang Persada 1986, Dirjen Pengairan, Departemen Pekerjaan Umum

Chang KT.2004. Introduction to Geographic Information Systems.2nd Edition. Iowa: McGraw-Hill

Emiyati. 2012. Hydrological Response Unit (HRU) dan Debit Aliran Daerah Aliran $\mathrm{Ci}$ Rasea. Thesis. Jurusan Geografi. Universitas Indonesia Press

Flugel, W. A. 1997. Combining GIS with regional hydrological modelling using hydrological response unit (HRUs). An application from Germany. Mathematics and Computers in Simulation 43 (297304). Elsevier.

Fitrian, Hani. 2002. Analisis Potensi dan Ketersediaan Air Berdasarkan Neraca Air di DAS Brantas Hulu, Jawa Timur. Jurusan Geofisika dan Meteorologi FMIPA IPB, Bogor

Handoko. 1995. Klimatologi Dasar. Jakarta : Pustaka Jaya

Gandasasmita K, Hadi SA, Saroinsonng FB. 2003. Data structure developing for land resources information storage and management (in Indonesian). The 10th National Seminat of Persada 3-4 July 2003. Nikko Hotel, Jakarta.

Junaidy, Edy dan Surya Dharma Tarigan. 2010. Penggunaan Model Hidrologi SWAT (Soil and Water Assessment Tool) Dalam Pengelolaan DAS Cisadane. Departemen Ilmu Tanah dan Sumberdaya Lahan, Fakultas Pertanian. IPB : Press.

Kodoatie dan Robert J. 2008. Pengelolaan Sumber Daya Air Terpadu. Yogyakarta: CV Andi Offset

Matlock M, Greg Thoma, Eric Cummings, Jackson Cothren, Mansoor Leh dan John Wilson. 2013. Geospatial Analysis of Potential Water Use, Water Stress and eutrophication impacts from US dairy 
production. International Dairy Journal. Departement Of Agriculture and Biological Engineering. University of Arkansas. Elsevier.

Tan, K. H. 1991. Dasar-Dasar Kimia Tanah. Terjemahan Goenadi, D.H. Gajah Mada University Press. Yogyakarta.

Soil Survey Staff. 1998. Key to Soil Taxonomy 8th edition. USDA-NRCS Washington DC.

Srinivasan, R dan Chris George. 2011. Map Window Interface for Soil and Water Assessment Tool (SWAT). United Nations University International Institute for Software Technology. Macao.

Zhang, X. 2006. Evaluations of Spatial Heterogenity of Watershed through HRU concept using SWAT. http://twri.tamu.edu/docs/funding/usgs/20 05-06/zhang (3 Juni 2014) [terhubung berkala] 